\title{
RESEARCH OF THE OVERALL CHEMICAL AND AMINO ACID COMPOSITION OF MEAT FROM YOUNG ANIMALS OF NEW SHEEP GENOTYPES
}

\section{Olga N. Orlova, ${ }^{\star}$ Vitaly S. Mkrtichyan, Ludmila V. Skrypnik, Ludmila V. Krichun}

North-Caucasian Branch of V. M. Gorbatov Federal Research Center for Food Systems of RAS, Rostov-on-Don, Russia

\begin{abstract}
Keywords: fatty acid profile, meat, quality characteristics, sheep
Abstract

The paper presents the results of the investigation of the overall chemical composition (mass fraction of moisture, fat, protein and ash) and the amino acid composition of mutton from the experimental animals of new genotypes: Sovetsky Merino $x$ Dzhalginsky Merino and Sovetsky Merino x Stavropolsky breed. As a control, meat of purebred Sovetsky Merino was studied. The experimental and control rams were slaughtered at the age of 8 months by the conventional technology. Meat samples for laboratory examination were taken a day after slaughter. The results of the analysis of the overall chemical composition showed that lamb meat of new genotypes had lower moisture content and higher content of fat and protein compared to the control. Analysis of the amino acid composition of meat proteins of genotypes Sovetsky Merino x Dzhalginsky Merino and Sovetsky Merino x Stavropolsky breed revealed lower content of essential amino acids compared to the control. Comparison of amino acid scores showed that the amino acid composition of meat proteins from the experimental animals was limited by valine and lysine, respectively. It was concluded by the results of the investigations of the amino acid composition of proteins that the biological full value of proteins of mutton from new genotypes was $22.9 \%$ and $30.3 \%$ lower than that of the control.
\end{abstract}

\section{Introduction}

Mutton has the specific chemical composition of muscle and fatty tissues, physico-mechanical and taste peculiarities [1-4]. Compared to pork, mutton has the higher content of protein but less fat. Mutton contains on average $18-20 \%$ of protein, $10-12 \%$ of fat, $0.85-0.95 \%$ of ash and $63-68 \%$ of water.

Mutton muscle tissue proteins contain all essential amino acids, which are balanced in the ratio that is most optimal for the human body. They include lysine, tryptophan, methionine, leucine, isoleucine, valine, threonine and phenylalanine. Lysine, tryptophan and methionine are considered most important [5].

Mutton is only slightly inferior to beef and pork in terms of the content of essential amino acids. The biological value, including the amino acid composition of meat from animals raised in various keeping conditions and with various feeding rations can be different [6,7].

Sheep are very mobile, energetic and strong animals adapted to traveling long distances in different terrains. In contrast to pork, mutton has the higher content of myoglobin, which is necessary to supply muscle tissue with oxygen; therefore, the muscle tissue color is more saturated and varies from red to brick-red $[8,9]$.

One of the main benefits of mutton is its hypoallergenicity, which is beneficial when using this raw material in food production for child nutrition. Mutton and its components are widely used for production of specialized gerodietetic foods because of their high nutritional value and unique functional properties [10].
Analysis of the meat chemical composition gives the full picture of its quality characteristics. The meat chemical composition is determined by many factors: species, age, fatness, breed and gender of an animal, as well as other traits. Among various meat types, mutton and especially lamb have high palatability, good assimilability and dietetic properties [11].

Mutton is a valuable component of human nutrition being a source of animal protein. By the balance of fatty acids and amino acids, content of vitamins and minerals, it is not inferior to beef; and by caloricity, it is even superior $[12,13,14,15]$.

Meat from lambs at the age of 6-8 months is considered the best. During the first 8 months of life, the most intensive deposition of the most valuable meat part (animal protein) takes place. As animals grow older, the carcass weight increases mainly due to fat deposition, which reduces the biological value of meat and economic efficiency of its production $[16,17,18,19]$.

Over the last years, a special emphasis has been placed on meat direction of sheep husbandry, in particular, raising and selling of lambs in the year of birth to produce lamb meat [20].

Modern selection in sheep husbandry is based on the rational use of the existing genetic resources of breeding animals, effective and timely reproduction of the herd, production of animals with desired physiological and morphological characteristics and optimal level of economic traits [21,22].

The progress of the agricultural production to a great extent depends on rates of genetic improvement of existing 
productive and biological characteristics of farm animals and creation of new ones.

A degree of manifestation of these traits determining quantitative and qualitative properties of manufactured products from sheep and their economic significance depend on hereditary traits of sheep, paratonic conditions and technological methods for production of this product type $[23,24,25,26,27]$.

The most important criteria for profitability of sheep husbandry are factors determining the genetic potential of mutton production $[28,29]$.

In Russia, the further development of sheep husbandry should be aimed towards the rational use of the genetic potential of animal breeds that allows optimal use of feed, energy and financial resources to obtain high quality and ecologically pure products $[30,31,32]$.

The growth in mutton production in our country is one of the reserves for increasing meat resources [33]. The variety of breeds and genetically isolated groups of sheep with the various degree of manifestation of individual productivity indicators and biological peculiarities create unlimited possibilities to increase production and improve quality of mutton.

Genetic diversity of local breeds can facilitate preservation of products that are economically necessary to improve sheep [34].

One of the ways to increase mutton output is creation of new sheep breeds and improvement of existing ones characterized by earliness and high meat productivity [35].

An increase in output of meat products in the country requires the search for ways of problem solution both by the selection genetic methods and by the technological methods. An important role in this regard is played by national breed resources that can ensure high realization of the genetic potential of productivity provided that necessary environmental conditions are created $[20,36]$.

Nowadays, sheep breeding is performed mainly by peasant farm enterprises [37].

Sheep productivity is formed under the action of a genotype and environmental conditions. Therefore, the task of achieving high productivity of sheep comes down to the full use of the genetic potential with creation of the favorable environmental conditions $[38,39,40]$.

Meat productivity of sheep is closely linked with the genetically conditioned heritability programmed for a certain potential of a sheep breed or type, as well as with the level of their feeding, keeping and handling system $[41,42,43,44]$.

In foreign countries, mutton production specializes largely in intensive raising and fattening of lambs and their slaughter at the age of 8-9 months. The leading lamb meat producers are China, Australia, United Kingdom, France, USA and Bulgaria, where high quality lamb meat is produced when slaughtering fattened lambs. This meat is characterized by the high palatability and nutritional value, and is in great demand in the European and Japanese markets [45].
In Russia, the existing sheep population adapted to local climatic conditions mainly has the wool and wool-andmeat direction of productivity. Sheep of meat direction of productivity account for less than $10 \%[46,47]$.

The most common sheep breed in our country is the fine wool breed Sovetsky Merino, which is resistant of the extreme climatic factors. In the process of breeding of this variety, two intrabreed directions of productivity were developed, namely, wool and wool-and-meat.

Sheep of the wool direction have low indices of meat productivity and meat quality due to the fact that their genetic and biological potential was used, first of all, for production of wool, sheepskin and so on. Processing of such animals for meat has low efficiency. Meat packing plants that process such sheep often bear losses, especially, when processing lean mutton.

According to the experience of foreign countries, a promising direction is an improvement of the genetic structure of a herd by methods of complex assessment and early diagnostics of sheep productive qualities $[48,49]$.

One of the ways to increasing meat productivity of sheep and mutton quality is two-way and three-way crossing. Practice of animal husbandry proves that superiority of hybrid animals over the parental forms prevails in an individual trait but not in the complex of traits [50].

Crossing is used on a large scale in our country and foreign countries such as Australia, USA, Germany, New Zealand and others. This is linked with the desire of sheep breeders to increase slaughter and meat quality of animals at the present stage [51].

In the modern conditions, the sheep husbandry direction oriented towards production of mutton and lamb meat has assumed great importance. The task of selection is to create such sheep. To perform this task it is necessary to know about the modern requirements for sheep husbandry products, including mutton, accumulated data on sheep and methods for implementation of these data into practice [22].

Prerequisites for sheep husbandry development that are formed in several regions of the country, including the Southern Federal District, together with social significance of this branch will facilitate its revival and sustainable development [52].

With that, there is deficiency of high quality mutton, which is evident from high prices that are not lower (and in many regions are higher) than prices on beef, which is still deficient.

The development of scientifically substantiated requirements for industrially suitable sheep and mutton by the meat processing industry is aimed towards the growth in meat productivity of animals and quality of produced meat, an increase in profitability of sheep breeding enterprises and meat processing plants, provision of the population with high quality mutton products, which is quite topical today. For example, similar requirements for pigs and meat [53], which were timely developed by VNIIMP 
in 2007, facilitated, among other things, full provision of the population with domestic pork.

The aim of this study was to investigate quality indicators of mutton from animals of new genotypes to develop scientifically substantiated requirements for industrially suitable sheep and mutton.

\section{Objects and methods}

The object of the research was an average sample of meat from the whole ovine carcass.

The overall chemical composition of mutton was determined using the following methods: moisture mass fraction by GOST $33319-2015^{1}$, fat mass fraction by GOST $23042-$ $2015^{2}$, protein mass fraction by GOST $25011-2017^{3}$, ash mass fraction by GOST 31727-2012 .

The amino acid composition of mutton was analyzed by GOST 34132-20175.

The amino acid score, a chemical method for detection of protein quality in foods, is based on comparison of the amino acid composition of products under study with the amino acid composition of the standard (ideal) protein.

The amino acid score for each of the amino acids was detected by the equation:

where:

$$
A S=\frac{C_{\text {tested }} \times 100 \%}{C_{\text {standart }}}
$$

$A S$ is the amino acid score, \%,

$C_{\text {tested }}$ is the content of the essential amino acid in $1 \mathrm{~g}$ of the tested protein, $\mathrm{mg}$,

$C_{\text {standard }}$ is the content of the essential amino acid in $1 \mathrm{~g}$ of the standard protein, $\mathrm{mg}$.

Simultaneously with analysis of the amino acid score, a limiting essential amino acid for a particular protein with the lowest score was determined.

\section{Results and discussion}

The study was carried out on hybrid young rams of the following genotypes:

Sovetsky Merino x Dzhalginsky Merino (SMxDzh, exp. 1) and Sovetsky Merino x Stavropolsky breed (SMxSb, exp. 2). As a control, purebred young rams of the Sovetsky Merino (SM) breed were used.

Young animals were raised up to the age of 8 months in the peasant farm enterprise Smorodin V. I. of the Tselinsky district of the Rostov region.

${ }^{1}$ GOST 33319-2015. "Meat and meat products. Method for determination of moisture content”. Moscow: Standartin-form, 2018. - 14 p. (In Russian)

${ }^{2}$ GOST 23042-2015 "Meat and meat products. Methods of fat determina tion". Moscow: Standartinform, 2019. - 8 p. (In Russian)

${ }^{3}$ GOST 25011-2017 "Meat and meat products. Protein determination methods". Moscow: Standartinform, 2018. — 14 p. (In Russian)

${ }^{4}$ GOST 31727-2012 (ISO 936:1998) "Meat and meat products. Determination of total ash". Moscow: Standartinform, 2019. - 11 p. (In Russian)

${ }^{5}$ GOST 34132-2017 "Meat and meat products. Determination of amino acids composition of animal protein". Moscow: Standartinform, 2017. 16 p. (In Russian)
The experimental and control animals were slaughtered in the meat packing plant in the village of Razvilnoe (Peschanokopsky district, Rostov oblast).

Average samples of meat from the whole ovine carcasses were taken a day after slaughter from each of chilled carcasses held in refrigerating chambers at a temperature of $0-4{ }^{\circ} \mathrm{C}$ and humidity of $90 \%$.

The overall chemical composition and the amino acid composition of the meat samples were analyzed in the laboratory conditions of the V. M. Gorbatov Federal Research Center for Food Systems of RAS (Moscow) and its NorthCaucasian Branch (Rostov-on-Don).

The results of the overall chemical composition of meat from lambs of new genotypes are presented in Figures 1-4.

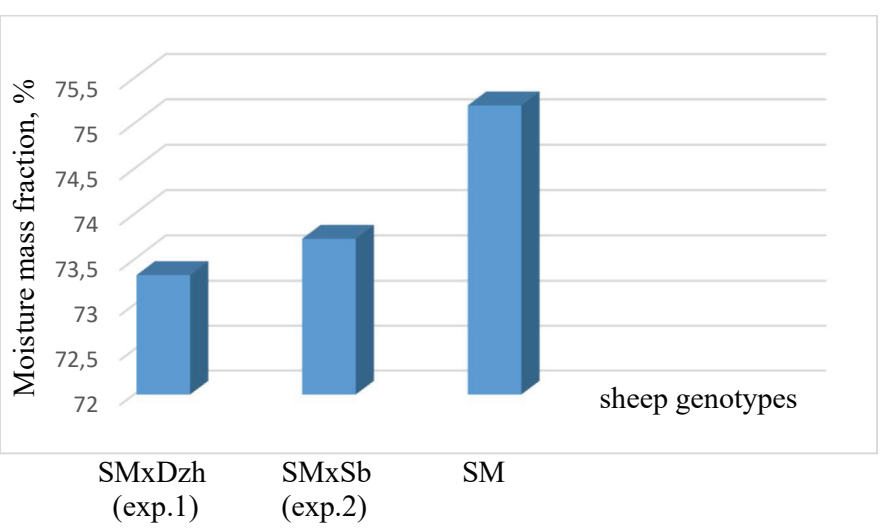

Figure 1. Moisture mass fraction in meat from sheep of new genotypes, $\%$

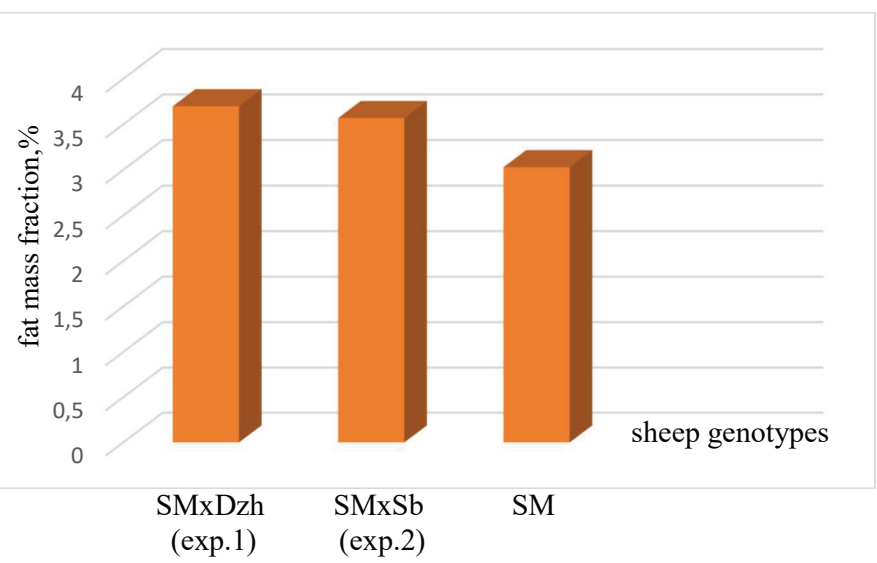

Figure 2. Fat mass fraction in meat from sheep of new genotypes, $\%$

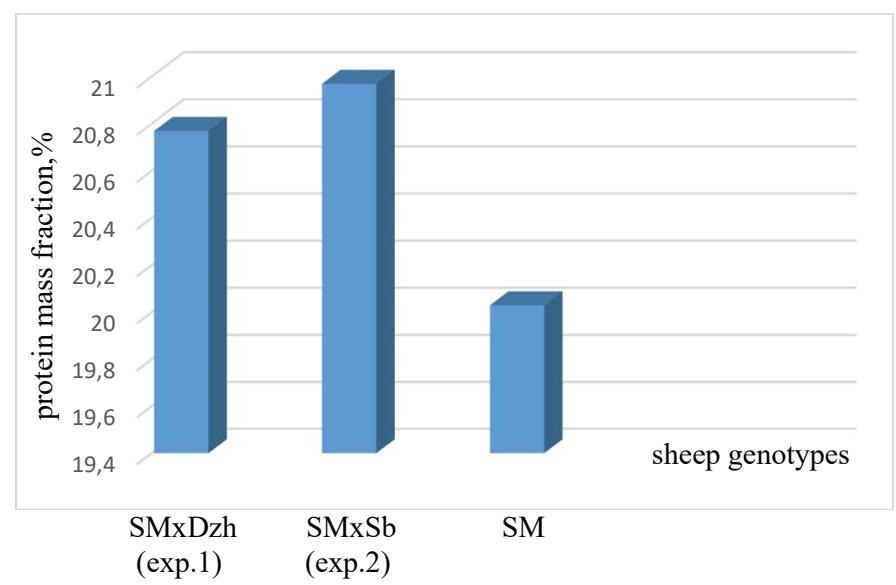

Figure 3. Protein mass fraction in meat from sheep of new genotypes, $\%$ 


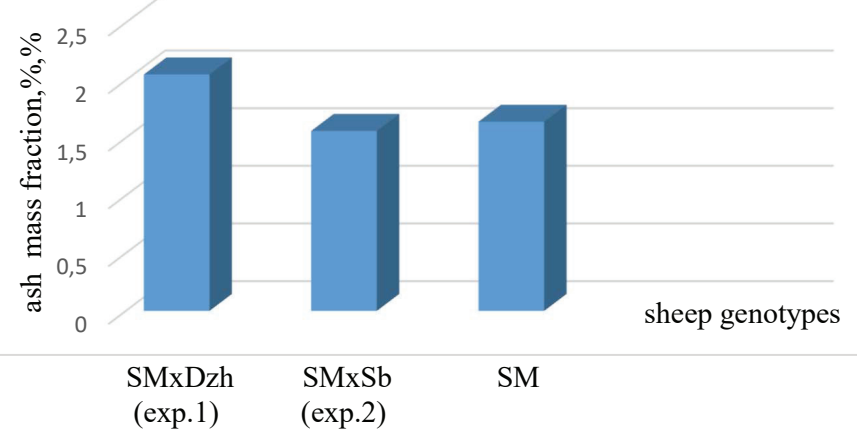

Figure 4. Ash mass fraction in meat from sheep of new genotypes, $\%$

It was established that compared to the control, meat from sheep of new genotypes (in experiments 1 and 2) had:

- lower moisture content by $1.87 \%$ and $1.47 \%$, respectively (Figure 1);

- higher fat content by $0.67 \%$ and $0.54 \%$, respectively (Figure 2); the maximum fat content in mutton was in experiment $1(3.70 \%)$;

- higher protein content by $0.74 \%$ and $0.94 \%$, respectively (Figure 3); the maximum protein content in mutton was in experiment 2 (20.97\%).

Meat from sheep of new genotypes (Figure 4) had the higher ash content (by $0.41 \%$ ) in experiment 1 and lower ash content (by $0.08 \%$ ) in experiment 2 compared to the control.

The mean values of the amino acid composition of meat from young animals of new genotypes are presented in Table 1 .

Table 1. Mean values of the amino acid composition of proteins in meat from young rams of new genotypes

\begin{tabular}{|c|c|c|c|c|c|c|}
\hline \multirow[b]{2}{*}{ Amino acids } & \multicolumn{3}{|c|}{$\begin{array}{c}\text { Content, } \\
\text { g/100g meat }\end{array}$} & \multicolumn{3}{|c|}{$\begin{array}{l}\text { Content, } \\
\text { g/100g protein }\end{array}$} \\
\hline & $\sum_{\infty}$ & $\sum_{i=1}^{\frac{\pi}{N}}$ & $\sum_{\hbar}^{\infty}$ & $\sum_{\infty}$ & $\sum_{\text {苓 }}^{\frac{1}{N}}$ & $\sum_{\infty}^{\infty}$ \\
\hline Essential amino acids & 8.00 & 6.70 & 6.00 & 40.0 & 32.4 & 28.7 \\
\hline \multicolumn{7}{|l|}{ including: } \\
\hline Valine & 1.00 & 0.70 & 0.70 & 5.00 & 3.4 & 3.3 \\
\hline Isoleucine & 1.30 & 0.90 & 0.90 & 6.5 & 4.3 & 4.3 \\
\hline Leucine & 1.60 & 1.10 & 0.90 & 8.0 & 5.3 & 4.3 \\
\hline Lysine & 1.00 & 0.80 & 0.70 & 5.0 & 3.8 & 3.3 \\
\hline Methionine & 0.60 & 0.50 & 0.30 & 3.0 & 2.4 & 1.5 \\
\hline Threonine & 1.50 & 1.60 & 1.50 & 7.5 & 7.7 & 7.2 \\
\hline Tryptophan & 0.30 & 0.30 & 0.30 & 1.5 & 1.4 & 1.5 \\
\hline Phenylalanine & 0.70 & 0.80 & 0.70 & 3.5 & 3.8 & 3.3 \\
\hline Non-essential amino acids & 12.00 & 14.10 & 14.90 & 60.0 & 67.9 & 71.3 \\
\hline \multicolumn{7}{|l|}{ including: } \\
\hline Alanine & 1.40 & 1.00 & 0.90 & 7.0 & 4.8 & 4.3 \\
\hline Arginine & 1.00 & 0.70 & 0.50 & 5.0 & 3.4 & 2.4 \\
\hline Aspartic acid & 1.90 & 2.60 & 3.50 & 9.5 & 12.5 & 16.8 \\
\hline Histidine & 0.60 & 0.70 & 060 & 3.0 & 3.4 & 2.9 \\
\hline Glycine & 1.50 & 1.90 & 180 & 7.5 & 9.1 & 8.6 \\
\hline Glutamic acid & 2.90 & 4.60 & 5.10 & 14,5 & 22.2 & 24.4 \\
\hline Proline & 0.80 & 0.70 & 0.70 & 4.0 & 3.4 & 3.3 \\
\hline Serine & 1.10 & 1.20 & 1.20 & 5.5 & 5.8 & 5.7 \\
\hline Tyrosine & 0.50 & 0.40 & 0.40 & 2.5 & 1.9 & 1.9 \\
\hline Cysteine & 0.30 & 0.30 & 0.20 & 1.5 & 1.4 & 1.0 \\
\hline Amino acids in total & 20.0 & 20.8 & 20.9 & 100.0 & 100.0 & 100.0 \\
\hline
\end{tabular}

The results of the analysis of the amino acid composition in mutton from sheep of new genotypes showed that the content of the essential amino acids in protein of meat from the experimental animals of the genotypes SMxDzh and $\mathrm{SMxSb}$ was lower than that in protein of meat from purebred SM (control) by $7.6 \%$ and $11.3 \%$, respectively.

The amino acid scores for each of the essential amino acid calculated according to the method described above are presented in Table 2.

Table 2. The amino acid score of protein in meat from young rams of new genotypes

\begin{tabular}{|c|c|c|c|c|c|c|c|}
\hline \multirow{2}{*}{ Amino acid } & \multirow{2}{*}{ 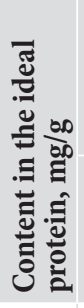 } & \multicolumn{3}{|c|}{$\begin{array}{c}\text { Content } \\
\text { in mutton } \\
\text { protein, } \\
\text { mg/g }\end{array}$} & \multicolumn{3}{|c|}{$\begin{array}{l}\text { Amino acid score } \\
\text { (AS), } \%\end{array}$} \\
\hline & & $\sum_{\infty}$ & $\sum_{\infty}^{\frac{1}{N}}$ & 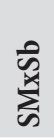 & $\sum_{\infty}$ & $\sum_{\infty}^{\frac{1}{n}}$ & $\sum_{\infty}^{\infty}$ \\
\hline Isoleucine & 40 & 65 & 43 & 43 & 162.5 & 107.5 & 107.5 \\
\hline Leucine & 70 & 80 & 53 & 43 & 114.3 & 75.7 & 61.4 \\
\hline Lysine & 55 & 50 & 38 & 33 & 90.9 & 69.1 & 60.0 \\
\hline Methionine + cystine & 35 & 45 & 38 & 25 & 128.6 & 108.6 & 71.4 \\
\hline Phenylalanine + Tyrosine & 60 & 60 & 57 & 52 & 100.0 & 95.0 & 115.4 \\
\hline Tryptophan & 10 & 15 & 14 & 15 & 150.0 & 140.0 & 150.0 \\
\hline Threonine & 40 & 75 & 77 & 72 & 187.5 & 192.5 & 180.0 \\
\hline Valine & 50 & 50 & 34 & 33 & 100.0 & 68.0 & 66.0 \\
\hline Limiting acid & & & & & \multicolumn{3}{|c|}{ lysine valine lysine } \\
\hline
\end{tabular}

It can be seen from Table 2 that:

1. Proteins of all experimental (SMxDzh and $\mathrm{SMxSb})$ and control (SM) mutton samples had the imbalanced essential amino acid content compared to the "ideal" protein recommended by $\mathrm{FAO} / \mathrm{WHO}$.

2. The amino acid compositions of proteins in the experimental mutton samples were not balanced by the following four amino acids: SMxDzh by valine, phenylalanine, leucine and lysine; SMxSb genotype by valine, methionine, leucine and lysine compared to the "ideal" protein.

The amino acid composition of the control mutton sample (SM) was not balanced only by one amino acid (lysine).

3. The amino acid composition of proteins in meat from the SMxDzh genotype was limited by valine (AS=68.0\%), the $\mathrm{SMxSb}$ genotype by lysine $(\mathrm{AS}=60.0 \%)$ and purebred young animals by lysine ( $\mathrm{AS}=90.9 \%$ ).

4. The biological full value of proteins from the experimental mutton samples obtained from new genotypes of sheep ( $\mathrm{SMxDzh}$ and $\mathrm{SMxSb})$ was lower than in the control sample (SM) from the purebred animals by $22.9 \%$ and $30.9 \%$, respectively.

Several information sources indicate that mutton protein is not lysine deficient $[54,55]$; on the contrary, its content is significantly higher than the level recommended by FAO/WHO (more than 170\%).

In an attempt to explain the obtained results of the investigation and quite a low content of lysine in the protein 
from all three sheep genotypes, we proceed from the fact that they all belong to the wool direction of productivity and are classified with fine-fleece sheep.

It is known that the genetic and biological potential of fine-fleece sheep is directed mainly towards "production" of fine wool according to the previous selection work.

We link the low lysine content in meat from lambs of the wool direction of productivity, to which Sovetsky Merino belong, with the increased use of this "building material" during coat formation in young animals, which is of top priority for this direction of productivity.

The main protein component of ovine wool is collagen, which is a protein with the complex amino acid composition containing essential amino acid lysine among others.

It was found that ovine wool achieves its optimal quality at the age of about 12 months.

In lambs, changes in several quality indicators (for example, strength) occuring in wool are associated with changes in collagen during animal growth.

Recent studies [56] established that ovine wool of young purebred and hybrid animals of the précoce breed at the age of 8 months contains collagen with the high level of lysine, which decreases by the age of 12 months as animals grow. For example, the content of lysine in protein from animals of the meat-and-wool type at the age of 8 months is 7.15\%$9.00 \%$, at the age of 12 months $5.10 \%-5.50 \%$. Similarly, it is $7.25 \%-8.52 \%$ and $6.04 \%-6.40 \%$ in animals of the wool-andmeat type at the age of 8 months and 12 months, respectively.

There is no doubt that a decrease with advancing age in the lysine expenditure on formation of hair collagen in animals enables increasing availability of this essential amino acid for construction of other proteins of the body, including meat (muscle) proteins.

Extrapolation of data obtained by sheep breeders when studying the amino acid composition of wool from young purebred and hybrid sheep of the précoce breed allows us to explain a low level of lysine in meat from young rams in our experiment and assume that the lysine deficiency in meat can decrease with age.

The result of the human selection activity, that is artificial selection, is not the only reason for this phenomenon. In our opinion, all this is linked with the natural selection.

Lambing takes place, mainly, in the second half of winter - at the beginning of spring. There is less than a year before the following winter. To survive during winter, lambs have to prepare well: grow, become stronger, gain superficial fat and, first of all, strong, warm wool cover.

In the course of the natural selection, individuals that had not prepared to winter died and those that had acquired necessary quality of fleece due to mutations survived. The genetic potential was directed exactly towards this with mobilization of all resources for this top priority task.

In connection with the new revealed circumstances, it was necessary to check our assumption by the experimental way.

Taking into account the available information about the fact that the deficiency of lysine, which is abundant in nuclear proteins (protamines and histones) causes retardation of the growth in the protein biosynthesis (and it is actually observed as our experiments show), it was necessary to do an experiment on inclusion of this amino acid into the feeding ration of animals not only for improvement of the biological full-value of meat proteins but also for possible acceleration of the growth of young sheep and improvement of meat productivity.

Industrial production of synthetic amino acids and their rational theoretically substantiated use in rations of farm animals is considered to be one of the most topical problems [57].

Inclusion of synthetic amino acids into the ration of growing young sheep in amount of 6-8g of lysine and 3-4 $\mathrm{g}$ of methionine per one feeding unit facilitates the enhancement of the redox processes, increase in productivity and other indicators [56].

In particular, it is possible to use the feed additive "Lysine sulfate" containing the active substance lysine in the quantity of not less than $70 \%$, as well as vitamins, microelements and other amino acids (methionine + cystine $0.35 \%$; methionine $0.30 \%$; threonine $0.56 \%$; tryptophan $0.10 \%$; arginine $0.56 \%$; isoleucine $0.39 \%$; leucine $0.63 \%$; valine $0.53 \%$; alanine $0.75 \%$; glycine $0.50 \%$; serine $0.31 \%$ and aspartic acid $0.80 \%$ ).

Lysine will facilitate assimilation of phosphorus, calcium and iron by the body, an increase in the hemoglobin content in blood, assist the digestive processes, improve biological value of food protein and rations in general.

\section{Conclusion}

The following conclusions were made based on the results of the analysis of the chemical and amino acid composition of meat from young animals of new genotypes:

1. Compared to the control, meat from sheep of the new genotype (SMxDzh, experiment 1$)$ had:

- lower moisture content by $1.87 \%$;

- higher fat and protein content by $0.67 \%$ and $0.74 \%$, respectively;

- lower content of essential amino acids by 7.6\%;

- amino acid composition of proteins limited by valine (AS $=68.0 \%)$;

- lower biological full value of proteins from mutton of the new genotype by $22.9 \%$ compared to the control;

2. Compared to the control, meat from sheep of the new genotype (SMxSb, experiment 2) had:

- lower moisture content by $1.47 \%$,

- higher fat and protein content by $0.54 \%$ and $0.94 \%$, respectively;

- lower content of essential amino acids by $11,3 \%$;

- amino acid composition of proteins limited by lysine $(\mathrm{AS}=60.0 \%)$;

- lower biological full value of proteins from mutton of the new genotype by $30.9 \%$ compared to the control.

3. Analysis of the amino acid composition of protein from all experimental and control meat samples indicate a deficiency of lysine compared to the "ideal protein". 
4. It was assumed that the low content of lysine in young animals is linked with the peculiarity of hair coat formation at the age of 8 months, which is characterized by an increased use of lysine for building wool collagen.

5. A method was proposed for improvement of lamb quality by using the feed additive "Lysine sulfate", which allows checking this hypothesis experimentally.
The obtained results of the analysis of the overall chemical and amino acid composition of meat from lambs of new genotypes will be used for the development of the scientifically substantiated requirements for industrially suitable sheep and mutton.

\section{REFERENCES}

1. Kosilov, V. I., Nikonova, E. A., Traisov, B. B., Yuldashbayev, Yu. A. (2018). Nutritional value of sheep meat of different genotypes. Sheep, goats, wool business, 3, 25-26. (In Russian)

2. Malysheva, Ye. S., Bessonova, N. M. (2016). The evaluation of mutton quality properties Bulletin of the Altai State Agrarian University. 4(138), 124-127. (In Russian)

3. Rózsáné, V. Z., Molnár, G., Jávor, A., Kukovics, S. (August 1923, 2002). Meat quaity comparision of different sheep genotypes in Hungary. Proceedings of the 7th World Congress on Genetics Applied to Livestock Production, Montpellier, France.

4. Klobukovskii, J., Brzostowski, H., Tański, Z., WiśniewskaPantak, D., Sowińska, J. (2002). The quality and nutritive value of the meat protein of various lamb genotypes. Polish Journal of Food and Nutrition Sciences, 52(4), 53-57.

5. Zabelina, M. V., Birkalova E. I. (2015). Meat and slaughter indicators of Russian long-tailed sheep, depending on sexual dimorphism and age. Sheep, goats, wool business, 3, 9-11. (In Russian) 6. Kashirina, N. A. Shatalova, E. M. (May 17-19, 2016). The chemical analysis and biological value of buck lambs of various breed affiliation. Production and processing of agricultural products: quality and safety management. Voronezh, Russia. (In Russian)

7. Gonzales-Barron, U., Popova, T., Bermúdez Piedra, R., Tolsdorf, A., Geß, A., Pires, J. et al. (2021). Fatty acid composition of lamb meat from Italian and German local breeds. Small Ruminant Research, 200, Article 106384. https://doi.org/10.1016/j. smallrumres.2021.106384

8. Aripov, T. T., Abdurasulov, A. H. (2016). Growth, development, measurements, exterior and buildcrossbred young sheep. Agricultural Bulletin of Stavropol Region, 1(21), 87-91. (In Russian)

9. Selionova, M.I., Podkorytov, N. A. (2021). Polymorphism of the gene GDF9 in sheep of Prikatun type of Altai Mountains breedand its correlation with indices of meat rate productivity. Theory and practice of meat processing, 6(1), 4-9. https://doi. org/10.21323/2414-438X-2021-6-1-4-9

10. Dimitrova, I., Bozhilova-Sakova, M. (2016). PCR-RFLP analysis of callipyge gene (CLPG) in karakachan sheep breed. Bulgarian Journal of Agricultural Science, 22(3), 482-484.

11. Dmitrik, I. I., Ovchinnikova, E. G. (2018). Food evaluation of young sheep meat of the bltavropol breed. Agricultural Journal, 1(11), 56-61. https://doi.org/10.25930/0372-3054-2018-111-65-71 (In Russian)

12. Sazonova, I. A. (2015). The nutritional value of the meat of the Volgograd breed of sheep, grown in the conditions of the Volga region. Sheep, goats, wool business, 3, 7-9. (In Russian)

13. Sazonova, I. A. (2015). Meat productivity and environmental safety of the meat of sheep of the Tsigai breed, depending on the natural and climatic zone of the Saratov region. Sheep, goats, wool business, 3, 18-20. (In Russian)

14. Kaić, A., Mioč, B. (2016). Fat tissue and fatty acid composition in lamb meat. [Masno tkivo i masnokiselinski sastav janjećeg mesa] Journal of Central European Agriculture, 17(3), 856-873. https://doi.org/10.5513/JCEA01/17.3.1783

15. Junkuszew, A., Nazar, P., Milerski, M., Margetin, M., Brodzki, P., Bazewicz, K. (2020). Chemical composition and fatty acid content in lamb and adult sheep meat. Archives Animal Breeding, 63(2), 261-268. https://doi.org/10.5194/aab-63-261-2020 16. Kolosov, Yu. A., Degtyar, E. A., Ganzenko, A. S. (2015). The influence of the genotype of sheep on the quality characteristics of meat. Sheep, goats, wool business, 4, 7-8. (In Russian)

17. Kosilov, V. I. Shkilev, P. N. Nikonova, E. A., Andreenko, D. A. Gazeev, I. R. (2017). Features of the formation of slaughter qualities of young sheep of different directions of productivity. Sheep, goats, wool business, 1, 19-21. (In Russian)

18. Lushnikov, V. P., Fomin, A.V., Sarbaev, M. G. (2016). Meat productivity of sheep of various genotypes. Sheep, goats, wool business, 4, 19-20. (In Russian)
19. Oner, Y., Ustuner, H., Orman, A., Yilmaz, O., Yilmaz, A. (2014). Genetic diversity of Kıvırcık sheep breed reared in different regions and its relationship with other sheep breeds in Turkey. Italian Journal of Animal Science, 13(3382), 588-593. https://doi. org/10.4081/ijas.2014.3382

20. Yuldashbayev, Yu. A., Shevhuzhev, A. F., Kochkarov, R. Kh., Mishvelov, E.G., Ponomareva, A.I. (2018). Meat productivity of young sheep karachai breed. Research Journal of Pharmaceutical, Biological and Chemical Sciences, 9(4), 692-699.

21. Avanus, K. (2015). Genetic variability of cast gene in native sheep breeds of turkey. [Türkiye yerli koyun irklarında cast genine ait genetik çeșitliliğin belirlenmesi]. Kafkas Universitesi Veteriner Fakultesi Dergisi, 21(6), 789-794. https://doi.org/10.9775/ kvfd.2015.13138

22. Trukhachev, V., Yatsyk, O., Telegina, E., Krivoruchko, A., Zhou, H., Hickford, J. G. H. (2018). Comparison of the myostatin (MSTN) gene in Russian Stavropol merino sheep and New Zealand merino sheep. Small Ruminant Research, 160, 103-106. https://doi. org/10.1016/j.smallrumres.2018.01.005

23. Ulyanov, A. N., Kulikova, A. Ya. (2017). Intensification of reproduction increases the efficiency of sheep breeding. Sheep, goats, wool business, 1, 10-11. (In Russian)

24. Shirokova, N. V., Skripin, P. V., Kobylyatsky, P. S., Romanets, T. S. (2017). Application of biotechnological techniques in the production of gourmet meat products. Scientific life, 4, 75-81. (In Russian)

25. Selionova, M. I., Bobryshova, G. T., Gadzhiev, Z. K., Izmalkov, S. A. (2017). Economics of sheep farming: pros and cons. Sheep, goats, wool business. № 1, 5-9. (In Russian)

26. Pavlov, A., Karmyshova, Y.V. (2018). Essence of the concept "rural territories" in the context of realization of the public agrarian policy of Russia. International Agricultural Journal, 61(1), 2 https://doi.org/10.24411/2588-0209-2018-10008

27. Zharuk, L.V. (2017). The quality management the products of sheep breeding. Scientific bulletin of the "Askania-Nova", 10, 2632. (In Ukrainian)

28. Sadovoy, V. V., Selimov, M. A., Shchedrina, T. V., Nagdalian, A. A. (2016). Usage of biological active supplements in technology of prophilactic meat products. Research Journal of Pharmaceutical, Biological and Chemical Sciences, 7(5), 1861-1865.

29. Trukhachev, V. I., Moroz, V. A., Chernobay, E. N., Ismailov, I. S. (2016). Meat and interior features rams of different genotypes. Research Journal of Pharmaceutical, Biological and Chemical Sciences, 7(1), 1626-1630.

30. Grigoryan, L. N., Khatataev, S. A. (2016). Breeding base of sheep breeding in Russia. Sheep, goats, wool business, 1, 2-4. (In Russian)

31. Zabelina, M. V., Birkalova, E. I. (2015). Meat and slaughter indicators of Russian long-tailed sheep, depending on sexual dimorphism and age. Sheep, goats, wool business, 3, 9-11. (In Russian) 32. Filatov, A. S. (2018). The modern state and innovative directions of development of sheep breeding in the Volgograd region. Agricultural and food innovations, 1(1), 39-41. (In Russian)

33. Tsynguyeva V. V. (2015). Features of development of sheep breeding in Russia and in the world. Economics and Business: theory and practice, 1, 117-122. (In Russian)

34. Vargas Junior, F. M., Martins, C. F., Feijó, G. L.D., Teixeira, A., Leonardo, A. P., Ricardo, H. D. A. et al. (2019). Evaluation of genotype on fatty acid profile and sensory of meat of indigenous Pantaneiro sheep and Texel or Santa Inês crossbred finished on feedlot. Small Ruminant Research, 173, 17-22. https://doi. org/10.1016/j.smallrumres.02.003

35. Danilova, L. V., Andreeva, S. V., Levina, T. Yu. (2016). Assessment of meat productivity and quality of mutton produced in the Saratov region. The Agrarian Scientific Journal, 5, 57-62. (In Russian)

36. Selionova, M. I., Chizhova, L. N., Surzhikova, E. S., Podkorytov, N. A., Podkorytov, A. T., Voblikova, T. V. (2020). Meat productivity of 
sheep of the altai mountain breed of different genotypes according to the CAST and GDF9 genes. Paper presented at the IOP Conference Series: Earth and Environmental Science, 613(1), Article 012130. https://doi.org/10.1088/1755-1315/613/1/012130 37. Zabashta, N. N., Golovko, E. N., Sinelshchikova, I. A. (2018). Elements of technology of fattening lambs and young sheep for meat to develop baby foods. Science news in the agro-industrial complex, 2-2(11), 332-339. (In Russian)

38. Sazonova, I. A. (2017). The influence of environmental factors on the meat production of sheep in the Volga region. Sheep, goats, wool business, 4, 28-29. (In Russian)

39. Atavliyeva, S., Tarlykov P. (2018). Genetic history of sheep domestication. Eurasian Journal of Applied Biotechnology, 1, 3-9.

40. lovenko, V.M., Rukavnikova H. I. (2017) The relative adaptability of the sheep genotypes ascanian fine-fleece breed to the environment conditions. Scientific bulletin of the "Askania-Nova, 10, 33-38. (In Ukrainian)

41. Aboneev, V. V., Gorkovenko, L.G., Kulikova, A.Y., Tsapkina, N.I. (2016). Meat productivity of different origin young sheep. Zootechniya, 4, 16-17. (In Russian)

42. Karabaeva, M. E., Kolotova, N. A. (2015). Meat productivity and quality of meat of young sheep of different genotypes. Sheep, goats, wool business, 4, 23-26. (In Russian)

43. Serdyukov, I. G., Aboneev, V. V., Pavlov, M. B., Pavlov, A.M., Marchenko, V. V. (2017). Meat productivity of rams of the Dzhalginsky merino breed with a different tone of wool. Sheep, goats, wool business, 1, 34-36. (In Russian)

44. Ubushaev, B. S. (2016). The influence of the composition of the feeding diet on the meat productivity and quality of meat of young sheep. AgroEcolnfo, 4(26), 27. (In Russian)

45. Salamon, D., Gutierrez-Gil, B., Arranz, J. J., Barreta, J., Batinic, V., Dzidic, A. (2014). Genetic diversity and differentiation of 12 eastern adriatic and western dinaric native sheep breeds using microsatellites. Animal, 8(2), 200-207. https://doi.org/10.1017/ S1751731113002243

46. Ovsyanin, D. N., Petrunina, I. V. (2020). Meat industry of the agro-industrial complex (preliminary results). Meat and meat products market, 1, 2-23.

47. 47 Chamurliev, N. G., Filatov, A. S. (2014). The intensity of growth and slaughter qualities of the Volgograd breed of sheep and its crossbreeds with the Edilbaevskaya. Proceedings of Lower Volga Agro-University Complex: Science and Higher Education, 1(33), 176-179. (In Russian)

48. Alakilli, S. Y. M. (2015). Analysis of polymorphism of caplstatin and callipyge genes in saudi sheep breeds using PCR-
RFLP technique. International Journal of Pharmaceutical Sciences Review and Research, 30(1), 340-344.

49. Greguła-Kania, M., Gruszecki, T. M., Junkuszew, A., JuszczukKubiak, E., Florek, M. (2019). Association of CAST gene polymorphism with carcass value and meat quality in two synthetic lines of sheep. Meat Science, 154, 69-74. https://doi.org/10.1016/j. meatsci.2019.04.007

50. Dmitrik, I. I. (2020). Influence of crossbreeding and level of feeding on microstructural indicators of lamb. Chief animal technician, 9, 32-40. https://doi.org/10.33920/sel-03-2009-04 (In Russian) 51. 51.Hernández-Cruz, L., Ramírez-Bribiesca, J. E., GuerreroLegarreta, M. I., Hernández-Mendo, O., Crosby-Galvan, M. M., Hernández-Calva, L. M. (2009). Effects of crossbreeding on carcass and meat quality of Mexican lambs. [Efeito docruzamento sobre o rendimento de carcaça e a qualidade da carne de cordeiros mexicanos] Arquivo Brasileiro De Medicina Veterinaria e Zootecnia, 61(2), 475-483. https://doi.org/10.1590/S010209352009000200027

52. Aboneev, V. V., Tarchokov, T. T., Sukhanova, S. F., Aboneev, D. V., Aboneev, E. V., Marchenko, V. V. (2019). Improving the competitiveness of fine-wool sheep using local and world stud rams. Paper presented at the IOP Conference Series: Earth and Environmental Science, 341(1), Article 012045. https://doi. org/10.1088/1755-1315/341/1/012045

53. Lisitsyn, A. B. (2013). Pork quality: Standards and evaluation methods. Animal husbandry of Russia, S2, 35-37. (In Russian)

54. Sazonova, I. A. (2016). Biological value of meat in rams of edilbaevskaya breed farmed in two climatic zones of Volga region. Problems of Productive Animal Biology, 1, 76-83. (In Russian)

55. Ismailov, I. S., Chernobai, E. N., Tregubova, N. V. (2019). Correlation of amino acid metabolism and formation of productivity of young sheep. Agricultural Bulletin of Stavropol Region, 4(36), 21-25. https://doi.org/10.31279/2222-9345-2019-8-3621-25 (In Russian)

56. Gagloev, A. Ch., Negreeva, A. N., Yuryeva, E. V. (2016). Influence of selection of sheep on change amino-acid structure of wool at thoroughbred and crossbred offsprings. Bulletin of the Agro-industrial Complex of the Upper Volga region, 4(36), 62-66. (In Russian)

57. Slavov, R., Mihaylova, G., Ribarski, St., Pamukova, D., Panayotov, D., Dragnev, D. (2016). Amino acid composition of lamb meat from the North East Bulgarian fine fleece breed and its crossbreds with Australian merino and Ile de France from internal breeding. Agricultural Science and Technology, 8(3), 256-261. https://doi. org/10.15547/ast.2016.03.049

\section{AUTHOR INFORMATION}

Olga N. Orlova - candidate of economic sciences, director, North-Caucasian Branch of V. M. Gorbatov Federal Research Center for Food Systems of RAS. 203, Lermontovskaya Str., 344000, Rostov-on-Don, Russia.

Tel.: +7-8632-64-67-62, E-mail: WNIIMP-DON@yandex.ru

ORCID: https://orcid.org/0000-0002-7245-5173

* corresponding author

Vitaly S. Mkrtichyan — senior research scientist, North-Caucasian Branch of V. M. Gorbatov Federal Research Center for Food Systems of RAS. 203, Lermontovskaya Str., 344000, Rostov-on-Don, Russia.

Tel.: +7-8632-64-67-62, E-mail: WNIIMP-DON@yandex.ru

ORCID: https://orcid.org/0000-0002-5309-7657

Ludmila V. Skrypnik - research scientist, North-Caucasian Branch of V. M. Gorbatov Federal Research Center for Food Systems of RAS. 203, Lermontovskaya Str., 344000, Rostov-on-Don, Russia.

Tel.: +7-8632-64-67-62, E-mail: WNIIMP-DON@yandex.ru

ORCID: https://orcid.org/0000-0003-1683-0159

Ludmila V. Krichun — junior research scientist, North-Caucasian Branch of V. M. Gorbatov Federal Research Center for Food Systems of RAS.

203, Lermontovskaya Str., 344000, Rostov-on-Don, Russia.

Tel.: +7-8632-64-67-62, E-mail: WNIIMP-DON@yandex.ru

ORCID: https://orcid.org/0000-0002-0885-4516

All authors bear responsibility for the work and presented data.

All authors made an equal contribution to the work.

The authors were equally involved in writing the manuscript and bear the equal responsibility for plagiarism.

The authors declare no conflict of interest. 